Soil Sci. 130:193-199.

Ulrich, B. 1981. Okologische Gruppierung von Boden nach ihrem chemischen Bodenzustand. Z. Pflanzenernaehr. Bodenkd. 144:289305.

Ulrich, B. 1984. Effects of air pollution on forest ecosystems and
waters-The principles demonstrated at a case study in central Europe. Atmos. Environ. 18:621-628.

Weaver, G.T., P.K. Khanna, and F. Beese. 1985. Retention and transport of sulfate in a slightly acid forest soil. Soil Sci. Soc. Am J. 49:746-750.

\title{
Factors Affecting Anion Movement and Retention in Four Forest Soils ${ }^{1}$
}

\author{
Dale W. Johnson, Dale W. Cole, Helga Van Miegroet, and F. W. Horng ${ }^{2}$
}

\begin{abstract}
Three hypotheses concerning the movement and retention of anions in forest soils were tested in a series of laboratory and field studies on two Tennessee Ultisols with mixed deciduous forest cover and two Washington Inceptisols, one with deciduous (red alder $\mathrm{Al}$ nus rubra Bong.) and one with coniferous [Douglas-fir, Pseudotsuga menziesii (Mirb.) Franco] forest cover. The first hypothesis, that sulfate and phosphate retention was related to adsorption to free $\mathrm{Fe}$ and Al oxides, which were in turn related to soil parent material and degree of weathering, was not supported by results of laboratory and field studies. The young, relatively unweathered Washington Inceptisols adsorbed more phosphate and sulfate than the older, highly weathered Tennessee Ultisols, apparently because of greater amorphous (oxalate-extractable) $\mathrm{Fe}$ and $\mathrm{Al}$ in the former. The second hypothesis, that $\mathrm{NO}_{3}^{-}$retention was governed primarily by biological uptake, was supported. Nitrate adsorption by soils in laboratory column studies was negligible, but subsequent field studies showed that tree uptake in field plots greatly reduced the leaching of applied $\mathrm{NO}_{3}^{-}$in all but the $\mathrm{N}$-rich red alder plot. The third hypothesis, that inputs of mobile anions will reduce $\mathrm{pH}$ and concentrations of bicarbonate and adsorbing anions (e.g., sulfate), were supported by application of chloride as both acid and $\mathrm{Na}$ and $\mathrm{Ca}$ salts to soil columns in the laboratory. Sulfate concentration as well as bicarbonate concentrations in soil solutions were sensitive to solution $\mathbf{p H}$.
\end{abstract}

Additional Index Words: bicarbonate, $\mathrm{NO}_{3}^{-}, \mathrm{SO}_{4}^{2-}$, chloride, phosphate, adsorption, uptake, leaching.

Johnson, D.W., D.W. Cole, H. Van Miegroet, and F.W. Horng. 1986. Factors affecting anion movement and retention in four forest soils. Soil Sci. Soc. Am. J. 50:776-783.

$\mathrm{N}^{r}$ YE AND GREENLAND (1960) first suggested that leaching in forest soils is limited by a lack of mobile anions in the soil. According to this concept, leaching cannot occur without an anion (or anions) to maintain electrochemical neutrality in soil solution. Cole and Gessel (1965) and McColl and Cole (1968) first applied Nye and Greenland's concept to describe carbonic acid leaching in undisturbed, fertilized, and harvested conditions in a forest soil. Subsequent studies confirmed the important influence of anion pro-

\footnotetext{
'Research sponsored by the National Science Foundation's Ecosystem Studies Program (DEB-7824395) and Office of Health and Environmental Research, U. S. Dep. of Energy, under Contract no. DE-AC05-840R21400 with Martin Marietta Energy Systems, Inc. Publication no. 2642, Environmental Sciences Division, ORNL. Received 3 June 1985.

Research Staff Member, Environmental Sciences Div., Oak Ridge National Laboratory, Oak Ridge, TN 37831; and Professor; Research Assistant; and Research Assistant; College of Forest Resources, Univ. of Washington, Seattle, WA 96195.
}

duction and mobility on nutrient leaching following harvesting, fire, fertilization, wastewater application, and atmospheric sulfuric acid inputs or "acid rain" (reviewed by Johnson and Cole, 1980).

Among the major anions in soil solutions that can be involved in leaching processes, there are large differences in terms of their biotic and abiotic chemical reactions. The production and mobility of $\mathrm{NO}_{3}^{-}$is regulated almost entirely by biological processes (uptake, mineralization, nitrification), while for phosphate and sulfate soil chemical processes are more important. Anion adsorption (primarily to amorphous $\mathrm{Fe}$ and $\mathrm{Al}$ oxide surfaces) is a dominant mechanism for phosphate retention in soils and can be very important to sulfate mobility as well (Johnson and Cole, 1980). Both of these anions can enter into "specific" adsorption reactions on hydrous oxide surfaces (Hingston et al., 1967) in which anions enter into a coordination with a metal oxide and displace another anion (usually $\mathrm{OH}^{-}$). The latter is sometimes called ligand exchange (Hingston et al., 1967). Recent work by Rajan (1979) and Parfitt and Smart (1978) showed that ligand exchange is the dominant mechanism for $\mathrm{SO}_{4}^{2-}$ adsorption onto $\mathrm{Fe}$ and $\mathrm{Al}$ hydrous oxides.

Anion adsorption sites lie on the surfaces of colloids, and these surfaces can have a plus, minus, or zero charge depending upon $\mathrm{pH}$ (Yopps and Fuerstenau, 1964). At low pH, surfaces become positively charged because of $\mathrm{H}^{+}$adsorption, and anion adsorption is enhanced. At high $\mathrm{pH}$, surfaces become negatively charged because of $\mathrm{H}^{+}$dissociation (or $\mathrm{OH}^{-}$ adsorption), and anions may be repelled.

Bicarbonate is somewhat unique in that its production and mobility are affected by both chemical and biological processes. Equilibrium equations show that bicarbonate concentration in any solution is regulated by $\mathrm{CO}_{2}$ pressure and $\mathrm{pH}$. Carbon dioxide pressure is in turn affected by soil microbial and root respiration, soil porosity, soil moisture content, and soil depth (Wesseling, 1962). Soil solution pH can be affected by base saturation, the presence of buffering agents (such as organic acids), and the ionic strength of the soil solution (Reuss, 1978; 1983). The relationships between base saturation, ionic strength, and $\mathrm{pH}$ can be seen from a generalized selectivity coefficient that describes the exchange of cations and $\mathrm{H}^{+}$on cation exchange sites (Stumm and Morgan, 1970)

$$
Q=\frac{\left(\mathrm{H}^{+}\right)^{r}\left[\mathrm{C}^{r+}\right]}{\left(\mathrm{C}^{r+}\right)\left[\mathrm{H}^{+}\right]^{r}},
$$

where $Q=$ selectivity coefficient, () = exchange phase, 
[ ] = solution phase, $\mathrm{C}=$ cation, and $r=$ valence of cation.

Solving for $\mathrm{H}^{+}$, we have

$$
\left[\mathrm{H}^{+}\right]=\left[\frac{\left(\mathrm{H}^{+}\right)^{r}\left[\mathrm{C}^{r+}\right]}{\left(\mathrm{C}^{r+}\right) Q}\right]^{1 / r}
$$

This equation shows that we can change soil solution $\mathrm{pH}$ by changing exchangeable $\left(\mathrm{H}^{+}\right)$or $\left(\mathrm{C}^{r+}\right)$ (e.g., by changing base saturation) or by changing solution cation concentration, $\left[\mathrm{C}^{r+}\right]$. Generally, the pool of exchangeable cations or $\mathrm{H}^{+}$per unit of soil is much greater than the pool of solution cations of $\mathrm{H}^{+}$. Thus, changes in base saturation are more difficult to produce and longer in duration than those in solution concentrations, and for our purposes it is useful to separate the two into long- and short-term effects.

Since chloride is relatively unaffected by either biotic or abiotic chemical reactions in soils, it normally leaches through soils without reaction. However, the input of any mobile anion (such as $\mathrm{Cl}^{-}$) should result in a short-term lower soil solution $\mathrm{pH}$ whether the anion is input as a salt or as an acid. This is because the concentration of cations $\left[\mathrm{C}^{r+}\right]$ will be elevated concomitantly with the concentration of the introduced anion in soil solution, and this will in turn elevate $\left[\mathrm{H}^{+}\right]$according to Eq. [2]. In the case of an acid input, $\mathrm{H}^{+}$will displace exchange cations, lowering base saturation, and in this way induce a long-term decrease in $\mathrm{pH}$ and total ionic leaching following the passage of the initial flux. In the case of a salt addition, there should be some $\mathrm{H}^{+}$displacement by incoming cations (by mass action), resulting in a long-term increase in base saturation, $\mathrm{pH}$, and total ionic leaching following the initial flux. Thus, although $\mathrm{Cl}^{-}$(or any other mobile anion) itself may pass through the soil unaffected, it can have both short- and long-term effects on the mobilities of other anions and on total ionic flux.

As a result of the considerations outlined above, we constructed the following hypotheses concerning anion mobility in forest soils:

\section{Hypothesis I:}

The mobility of sulfate and phosphate in soil is related to the free $\mathrm{Fe}$ and $\mathrm{Al}$ content of the soil which, in turn, is a function of the original chemical composition of the soil and the degree to which it has been weathered.

\section{Hypothesis II:}

The mobility of $\mathrm{NO}_{3}^{-}$is controlled by biological uptake rather than abiotic chemical processes.

\section{Hypothesis III:}

Although mobile, biologically inactive anions such as $\mathrm{Cl}^{-}$will pass through the soil unaffected, the additions of such anions as salts or acids will have both short- and long-term effects on soil solution $\mathrm{pH}$ and on the mobilities of other anions, thus effecting an increase or decrease in net ionic flux from the soil.

These hypotheses were tested in a variety of laboratory and field experiments on two Ultisols with mixed deciduous forest cover in eastern Tennessee and two Inceptisols, one with coniferous [Douglas-fir, Pseudotsuga menziesii (Mirb.) Franco] and one with deciduous (red alder, Alnus rubra Bong.) cover in western Washington. Results of these tests are summarized in this paper.

\section{SITES}

\section{Walker Branch Watershed, Tennessee}

Walker Branch Watershed is situated in the ridge and valley physiographic province near Oak Ridge, TN (Grigal and Goldstein, 1971). The climate type is humid mesothermal with moderate summer and winter temperatures. Mean annual temperature is $14.3^{\circ} \mathrm{C}$ and precipitation averages 151 $\mathrm{cm} / \mathrm{yr}$, mostly as rain (Henderson et al., 1977). Soils of the watershed are primarily Ultisols derived from Knox dolomite, a cherty, dense to coarsely crystalline rock of late Cambrian to early Ordovician age. Soil coarse fractions consist of chert, $\mathrm{Fe}-\mathrm{Mn}$ nodules, and quartz. Clay fractions consist primarily of kaolinite with lesser amounts of vermiculite, hydrous micas, and quartz, (Peters et al., 1970). In a nearby site with similar parent material, Lee et al. (1984) concluded that kaolinite was weathering to Al hydroxy-interlayered vermiculite in surface horizons.

The chestnut oak (Quercus prinus L.) stand on Walker Branch is located on a ridgetop on the Fullerton series soil, a Typic Paleudult. Coarse fragments range from $30 \%$ in E horizons to 17 to $18 \%$, in $\mathrm{Bt}$ horizons and clay content ranges from 3 to $12 \%$ in E horizons to 40 to $50 \%$ in Bt horizons (Peters et al., 1970). Vegetation type is chestnut oak, described by Grigal and Goldstein (1971). Species consist primarily of chestnut oak, hickory (Carya spp.), red maple (Acer rubrum L.), white oak (Quercus alba L.), black oak (Q.velutina Lam.), blackgum (Nyssa sylvatica Marsh.), sourwood (Oxydendrum arboreum L.), and yellow-poplar (Liriodendron tulipifera L.), with occasional dogwood (Cornus florida L.) and northern red oak (Q. rubra L.). Understory is absent.

The yellow-poplar stand is located in a sinkhole depression on the Tarklin series soil, a Typic Fragiudult. Coarse fragments range from $7 \%$ in Ap horizons to 12 to $17 \%$ in $\mathrm{Bt}$ horizons and clay content ranges from 4 to $7 \%$ in Ap horizons to 12 to $17 \%$ in Bt horizons (Peters et al., 1970). Vegetation type is yellow-poplar, described by Grigal and Goldstein (1971). Species consist primarily of yellow-poplar with occasional red maple, white oak, black locust (Robinia pseudoacacia L.), persimmon (Diospyros virginiana L.), black cherry (Prunus serotina Ehrh.), and Carolina buckthorn (Rhamnus caroliniana D.C.). Understory consists of dogwood, occasional eastern red cedar (Juniperus virginiana L.), and Japanese honeysuckle (Lonicera japonica Thunb.).

\section{Thompson Site, Washington}

The Thompson site is located in the western foothills of the Cascade Mountains near Landsburg, WA. The climate type is maritime with cool, dry summers, and wet, moderate winters. Mean annual temperature is $9.8^{\circ} \mathrm{C}$ and mean annual precipitation is $136 \mathrm{~cm}$, most of which falls as rain between October and March. The soil at the study site belongs to the Alderwood series, a Dystric Entic Durochrept, and is composed of loosely consolidated ablation till of varying depth over a compacted basal till. Brackett (1966) found a predominance of quartz and feldspar with lesser amounts of chlorite, plagioclase, and chalcedony in the very fine sand fraction of this soil. The predominant clay mineral was found to be vermiculite.

The research plots are located in a naturally regenerated 48-yr-old stand of red alder and in an immediately adjacent 48-yr-old plantation of Douglas-fir. The understory in the 


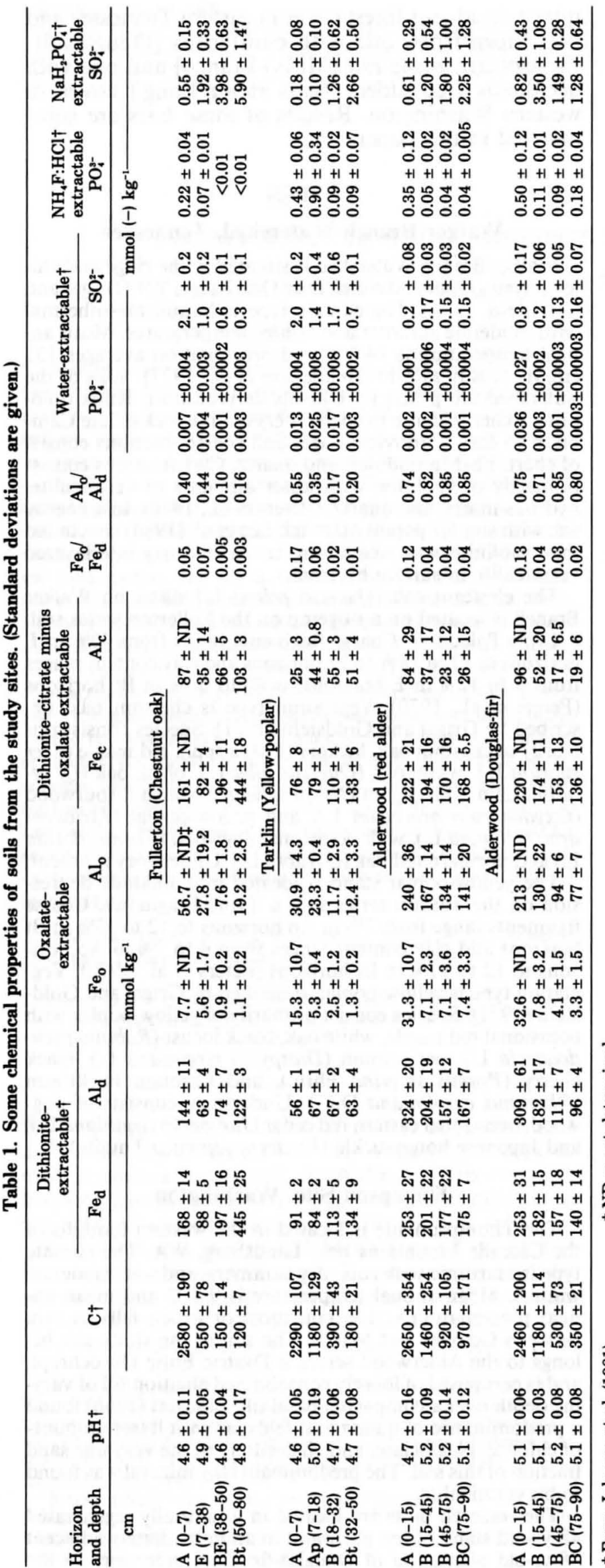

red alder stand is dominated by sword fern [Polystichum munitum (Kaulf.) Presl.] intermixed with occasional western hemlock [Tsuga heterophylla (Raf.) Sarg.], huckleberry (Vaccinium parviflorum Smith), vine maple (Acer circinatum Pursh.), Oregon grape [Berberis nervosa (Pursh.) Nutt.], and elderberry (Sambucus callicarpa Pursh.). Understory in the Douglas-fir stand is much less predominant and consists of salal (Gualtheria shallon Pursh.), Oregon grape, huckleberry, and mosses.

\section{METHODS}

\section{Field Studies}

At each of the four study sites, four 6- by 6-m plots were laid out. At Walker Branch, a soil pit (approximately 0.5 by $0.75 \mathrm{~m}$ at the surface) was dug in the center of each plot; at the Thompson site, a larger soil pit (approximately 1 by 2.5 $\mathrm{m}$ at the surface) was dug between pairs of plots. Soil samples were taken proportionally by horizon (i.e., a column of soil was taken from the entire horizon depth) from the pit walls prior to lysimeter installation. Soils were analyzed for a number of chemical and physical properties (Johnson et al., 1981). Those relevant to this study included $\mathrm{pH}(1: 1$ ratio in water); total C (LECO combustion), dithionite-citrate and oxalate-extractable $\mathrm{Fe}$ and $\mathrm{Al}$ (USDA, 1972), $\mathrm{NH}_{4} \mathrm{~F}$ / $\mathrm{HCl}$-extractable $\mathrm{PO}_{4}^{3-}$ (Olson and Sommers, 1982), Na$\mathrm{H}_{2} \mathrm{PO}_{4}$-extractable $\mathrm{SO}_{4}^{2-}$ (Johnson and Henderson, 1979), and water-extractable $\mathrm{PO}_{4}^{3-}$ and $\mathrm{SO}_{4}^{2-}$ (1:20 soil solution ratio; shaking for $1 \mathrm{~h}$ ). Iron and $\mathrm{Al}$ in the extractant solutions were analyzed by atomic absorption, $\mathrm{PO}_{4}^{3-}$ in the $\mathrm{NH}_{4} \mathrm{~F} / \mathrm{HCl}$ extractant solution was analyzed by Technicon Autoanalyzer, $\mathrm{SO}_{4}^{2-}$ in the $\mathrm{NaH}_{2} \mathrm{PO}_{4}$ extract solution was analyzed by the $\mathrm{Ba}$ chloranilate procedure of Bertolacini and Barney (1957), and $\mathrm{PO}_{4}^{3-}$ and $\mathrm{SO}_{4}^{2-}$ in the water extracts were analyzed by Technicon Autoanalyzer. Detection limits are $<0.1 \mathrm{mmol}$ $\mathrm{kg}^{-1}$ for $\mathrm{C},<0.002 \mathrm{mmol} \mathrm{kg}^{-1}$ for citrate-dithionite $\mathrm{Fe}$ and $\mathrm{Al},<0.2$ and $<0.7 \mathrm{mmol} \mathrm{kg} \mathrm{kg}^{-1}$ for oxalate-extractable $\mathrm{Fe}$ and $\mathrm{Al}$ (respectively), $<0.01 \mathrm{mmol} \mathrm{k^{-1 }}$ for $\mathrm{NH}_{4} \mathrm{~F} / \mathrm{HCl}$-extractable $\mathrm{PO}_{4}^{3-},<0.05 \mathrm{mmol} \mathrm{kg}^{-1}$ for $\mathrm{NaH}_{2} \mathrm{PO}_{4}$-extractable $\mathrm{SO}_{4}^{2-}$, and $<0.01 \mathrm{mmol} \mathrm{kg}^{-1}$ for water-extractable $\mathrm{PO}_{4}^{3-}$ and $\mathrm{SO}_{4}^{2-}$.

Tension lysimeters were installed in the A $(8 \mathrm{~cm})$ and B horizons $(50-80 \mathrm{~cm})$ of each plot. Solutions were collected continuously at $10-\mathrm{kPa}$ tension and sampled on approximately a 30-d basis (more frequently during rainy periods and less frequently during droughty periods).

After $120 \mathrm{~d}$ of monitoring the lysimeter waters, one of the four plots was treated with $0.5 \mathrm{~mol}(-) \mathrm{m}^{-2}$ of $\mathrm{NaH}_{2} \mathrm{PO}_{4}$ $\mathrm{Na}_{2} \mathrm{SO}_{4}, \mathrm{NaCl}$, and $\mathrm{NaNO}_{3}$ salts as a test of Hypotheses I and II.

Water samples were analyzed at each institution separately (Analytical Chemistry Division at ORNL and the College of Forest Resources at the Univ. of Washington, Seattle). Cross comparisons between laboratories were made and results were comparable. All waters were analyzed for $\mathrm{pH}$, conductivity, $\mathrm{Ca}^{2+}, \mathrm{Mg}^{2+}, \mathrm{K}^{+}$, and $\mathrm{Na}^{+}$(the latter four by atomic absorption); for $\mathrm{NH}_{4}^{+}, \mathrm{NO}_{3}^{-}, \mathrm{PO}_{4}^{3-}, \mathrm{Cl}^{-}$, and $\mathrm{SO}_{4}^{2-}$ (by Technicon Autoanalyzer); and for alkalinity by titration. Detection limits were $<0.005 \mathrm{mmol} \mathrm{L}^{-1}$ in all cases. Further checks of analyses were made by charge balance between - cations and anions and by comparing calculated with measured conductivity (Golterman and Clymo, 1969).

\section{Laboratory Studies}

As additional tests of Hypotheses I and II, anion adsorption isotherms were determined at ORNL on the soils from the four sites before treatment (one each per horizon and treatment plot, giving four replicates per horizon per site). Successive $50-\mathrm{mL}$ aliquots of $0.5,1.0,2.5$, and $5.0 \mathrm{mmol}(-)$ $\mathrm{L}^{-1}$ of $\mathrm{Cl}^{-}, \mathrm{NO}_{3}^{-}, \mathrm{H}_{2} \mathrm{PO}_{4}^{-}$as $\mathrm{Na}^{+}$salts, and $\mathrm{SO}_{4}^{2-}$ as $\mathrm{Na}^{+}$ 
and $\mathrm{Ca}^{2+}$, salts (using separate soil samples for each salt) were applied to 5-g air-dried, sieved $(<2 \mathrm{~mm})$ soil in a mechanical vacuum extractor (Concept Engineering, Inc.) at a $1-$ h extraction time setting. Each column $(2.5-\mathrm{cm}$ diam by 13.2-cm length) was prepacked with $1 \mathrm{~g}$ of ashless filter pulp, and two columns were left without soils (as blanks). Adsorption or desorption of anions was calculated by disappearance or appearance of anions in the eluent solution (after accounting for interstitial water and blank adsorptiondesorption) as described by Johnson and Henderson (1979). Calculated soil anion contents during adsorption studies included pretreatment soil anion previously determined as described above. Anion adsorption studies originally done with $\mathrm{Na}^{+}$salts gave extremely variable results except in the case of phosphate. Sulfate adsorption was done again using $\mathrm{Ca}^{2+}$ salts with much more satisfactory results (i.e., less variation and more differentiation among soils). No $\mathrm{Cl}^{-}$or $\mathrm{NO}_{3}^{-}$adsorption was noted in any soil, and thus only phosphate and $\mathrm{SO}_{4}^{2-}$ adsorption results are shown here.

A final test of Hypotheses I and II was made by setting up a column study to duplicate field $\mathrm{Na}^{+}$salt applications. Triplicate columns of the type described above were filled with 30-g samples of air-dried, sieved A and B horizon soils sampled before treatment from each salt-treated plot. The A horizon columns were pretreated with approximately 250 $\mu \mathrm{mol}(-)$ each of $\mathrm{Cl}^{-}, \mathrm{NO}_{3}^{-}, \mathrm{H}_{2} \mathrm{PO}_{4}^{-}$, and $\mathrm{SO}_{4}^{-}$as $\mathrm{Na}^{+}$salts. (Actual input values as determined by outputs from columns without soil, varied from $235 \mu \mathrm{mol}(-)$ to $280 \mu \mathrm{mol}(-)$ per column). These columns were then leached with four $150-\mathrm{mL}$ aliquots of distilled water, of which $75 \mathrm{~mL}$ was kept for analysis and $75 \mathrm{~mL}$ was leached through $\mathrm{B}$ horizon columns. All waters were analyzed for $\mathrm{pH}, \mathrm{HCO}_{3}^{-}, \mathrm{H}_{2} \mathrm{PO}_{4}^{-}$, $\mathrm{SO}_{4}^{2-}, \mathrm{Cl}^{-}, \mathrm{NO}_{3}^{-}$, and conductivity.

A second column study was set up to test Hypothesis III using soils from the Fullerton and Douglas-fir control plots. The A and B horizon columns were set up as described above. Triplicate A horizon columns were leached with $4150-\mathrm{mL}$ aliquots of $\mathrm{H}_{2} \mathrm{O}, \mathrm{HCl}, \mathrm{NaCl}$, and $\mathrm{CaCl}_{2}$, the latter at concentrations of $1.0 \mathrm{mmol}(-) \mathrm{L}^{-1}$. The $\mathrm{B}$-horizon columns were leached with $75-\mathrm{mL}$ of the $150-\mathrm{mL}$ A-horizon leachates. All waters were analyzed for $\mathrm{pH}, \mathrm{HCO}_{3}^{-}, \mathrm{SO}_{4}^{2-}, \mathrm{NO}_{3}^{-}$, $\mathrm{H}_{2} \mathrm{PO}_{4}^{-}, \mathrm{Cl}^{-}$, conductivity and $\mathrm{Al}^{3+}$ (the latter by atomic absorption).

Statistical analyses (standard deviation calculations, Duncan's multiple range test) were performed using SAS (SAS Institute, 1982).

\section{RESULTS AND DISCUSSION}

With one exception (dithionite-citrate-extractable $\mathrm{Fe}\left[\mathrm{Fe}_{\mathrm{d}}\right]$ in the Fullerton Bt horizon), the Washington (Alderwood) soils were as high or higher in $\mathrm{Fe}$ and $\mathrm{Al}$ hydrous oxides than the Tennessee (Fullerton and Tarklin) soils (Table 1). This was especially so for oxalate-extractable $\mathrm{Al}\left(\mathrm{Al}_{\mathrm{o}}\right)$ where the Washington soils had 4 to 10 times greater contents than the Tennessee soils (Table 1). The Washington soils also had approximately 1.5 to 4 times greater oxalate-extractable $\mathrm{Fe}\left(\mathrm{Fe}_{\mathrm{o}}\right)$ contents and approximately two times greater surface soil dithionite-extractable $\mathrm{Al}\left(\mathrm{Al}_{\mathrm{d}}\right)$ contents than the Tennessee soils (Table 1).

The ratio $\mathrm{Fe}_{\mathrm{o}} / \mathrm{Fe}_{\mathrm{d}}$ gives an index of the crystallinity of $\mathrm{Fe}$ hydrous oxides, which in turn provides an index of the degree of aging (Blume and Schwertmann, 1966). According to this index, Fe hydrous oxides in the Washington soils are only slightly less crystalline than those in the Tennessee soils (Table 1). The meaning of the $\mathrm{Al}_{\mathrm{o}} / \mathrm{Al}_{\mathrm{d}}$ ratio in terms of $\mathrm{Al}$ crystallinity is not well-defined (Blume and Schwertmann, 1966; Mc-
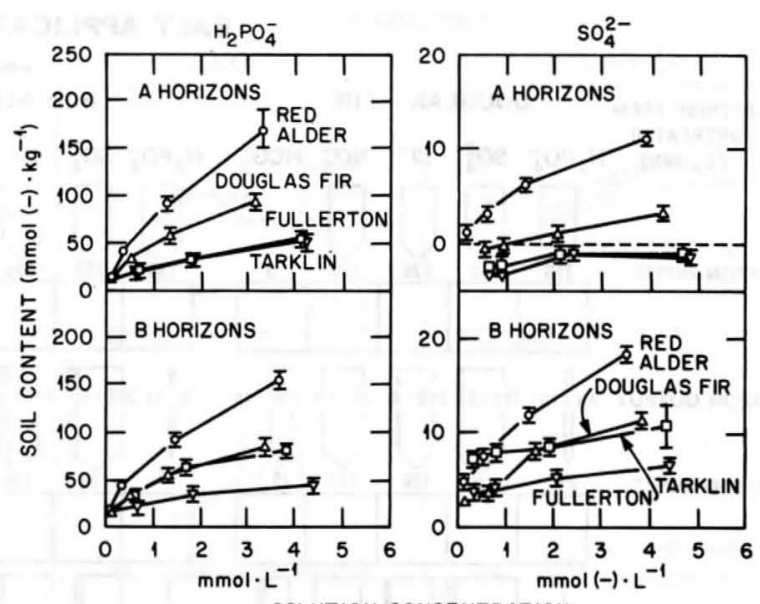

SOLUTION CONCENTRATION

Fig. 1. Phosphate and sulfate adsorption isotherms for the four study soils. (Standard deviations are given.)

Keague and Day, 1966), but it is worth noting that these ratios are considerably higher for the Washington than for the Tennessee soils (Table 1).

McKeague and Day (1966) note that the difference between $\mathrm{Fe}_{\mathrm{d}}$ and $\mathrm{Fe}_{\mathrm{o}}$, or $\mathrm{Fe}_{\mathrm{c}}=\mathrm{Fe}_{\mathrm{d}}-\mathrm{Fe}_{\mathrm{o}}$ provided a good chemical index of crystalline $\mathrm{Fe}$ hydrous oxide content. Again, the meaning of $\mathrm{Al}_{c}=\mathrm{Al}_{\mathrm{d}}-$ and $\mathrm{Al}_{\mathrm{o}}$ is less clear. In any event, the Washington soils have higher $\mathrm{Fe}_{\mathrm{c}}$ and $\mathrm{Al}_{\mathrm{c}}$ contents in surface horizons but lower $\mathrm{Al}_{\mathrm{c}}$ contents in subsurface horizons than the Tennessee soils (Table 1). For subsurface horizon $\mathrm{Fe}_{\mathrm{c}}$, the Fullerton soil was by far the highest and the other soils were about equal.

The phosphate and sulfate adsorption isotherms were very similar to one another in terms of relative curve positions and shapes for the various soils (Fig. 1). For both anions, the A horizon adsorption capacities were (in decreasing order) Red alder $>$ Douglasfir $>$ Fullerton $\simeq$ Tarklin. In the B horizons, the capacities were Red alder $>$ Douglas-fir $\simeq$ Fullerton $>$ Tarklin. These patterns were most closely correlated with $\mathrm{Al}_{\mathrm{d}}$ and, to some extent, with $\mathrm{Al}_{\mathrm{o}}$ but not particularly well with $\mathrm{Fe}_{\mathrm{o}}, \mathrm{Fe}_{\mathrm{d}}, \mathrm{Al}_{\mathrm{c}}$, or $\mathrm{Fe}_{\mathrm{c}}$ (Table 1).

Johnson and Todd (1983) found that $\mathrm{Fe}_{\mathrm{c}}$ was most closely correlated with sulfate adsorption among a variety of forest soils. On the other hand, Parfitt and Smart (1978), in a more rigorous, mechanistic study, found that more highly crystalline $\mathrm{Fe}$ hydrous oxides (such as goethite and hematite) have lower sulfate adsorption capacities than less crystalline Fe hydrous oxides because of fewer singly-coordinated surface hydroxyl ions in the former. The results of the current study tend to support the view that highly crystalline Fe hydrous oxides are not particularly efficient at either sulfate or phosphate adsorption (in comparison, at least, to seemingly less crystalline Al hydrous oxides). This implies that Hypothesis I is false and leads to the alternative hypothesis that the most highly-weathered soils, with the most crystalline $\mathrm{Fe}$ and $\mathrm{Al}$ hydrous oxides, will have lower anion adsorption capacities than less weathered soils with lower $\mathrm{Fe}$ and $\mathrm{Al}$ hydrous oxide crystallinity.

The question remains as to the effect of organic matter. Some studies have shown that organic matter in- 


\section{SALT APPLICATION - COLUMN STUDY}

LEACHING FROM

DOUGLAS - FIR

UNTREATED

COLUMNS

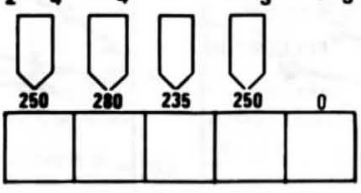

$\prod_{337 \pm 6} \prod_{240 \pm 4} \bigcap_{266 \pm 2}$

B HORIZON INPUT

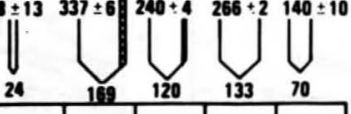

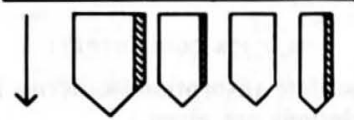

B HORIZON INPUT

FULLERTON
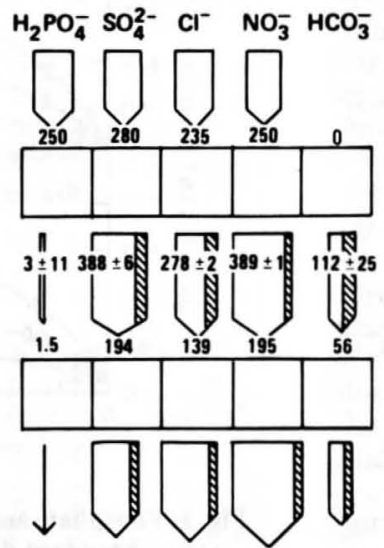

$\mathrm{SO}_{4}^{2-} \mathrm{Cl}^{-} \mathrm{NO}_{3}^{-} \mathrm{HCO}_{3}^{-}$
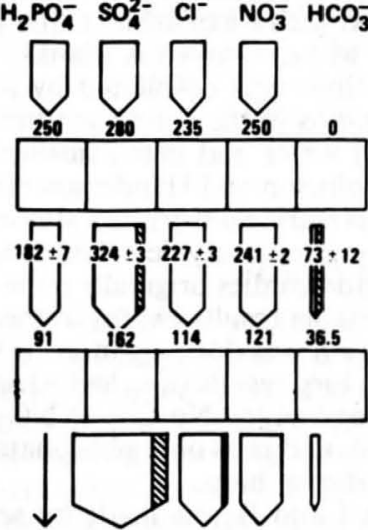

TARKLIN

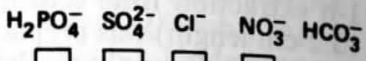

Fig. 2. Inputs and exports of anions from soil columns (30 g soil/column) treated with $\mathrm{H}_{2} \mathrm{PO}_{4}^{-}, \mathrm{SO}_{4}^{2-}, \mathrm{NO}_{3}^{-}$, and $\mathrm{Cl}^{-}$as $\mathrm{Na}^{+}$salts. The $\mathrm{A}$ horizon columns were treated with salts and leached with $150 \mathrm{~mL}$ of distilled water; $B$ horizon columns were leached with $75 \mathrm{~mL}$ of $A$ horizon leachate. Values for control columns leached with $\mathrm{H}_{2} \mathrm{O}$ only are shown at the right side of each output arrow. All values are in $\mu \mathrm{mol}(-)$ per column. (Standard deviations are given.)

hibits phosphate and sulfate adsorption (Guar, 1969; Larsen et al., 1959; Singh, 1984; Johnson and Todd, 1983). Other studies have shown that organic matter may enhance phosphate adsorption (Harter, 1969; Singh and Jones, 1976). Harter (1969) suggests that orthophosphate exchanges for $\mathrm{OH}^{-}$on organic matter as an initial reaction, following which $\mathrm{Fe}$ and $\mathrm{Al}$ complexes form. Singh and Jones (1976) found that organic matter low in phosphorus enhances orthophosphate adsorption, whereas the reverse is true for organic matter high in P. One possible explanation for these apparently contradictory results may be the inhibition of hydrous oxide crystallization by organic matter, as noted for Fe hydrous oxides by Schwertmann (1966) and Kodama and Schnitzer (1977). This inhibitory effect may maintain greater soil anion adsorption capacity by maintaining higher levels of amorphous, noncrystalline $\mathrm{Fe}$ and $\mathrm{Al}$ hydrous oxides (Parfitt and Smart, 1978). Counteracting this would be the negative (blocking) effect of organic ligand adsorption on phosphate and sulfate adsorption (Struth and Sieling, 1950; Larsen, et al., 1959; Singh, 1984), making the situation quite complex.

The negative effect of organic matter on $\mathrm{Fe}$ and $\mathrm{Al}$ crystallinity (as indexed by the $\mathrm{Fe}_{\mathrm{o}} / \mathrm{Fe}_{\mathrm{d}}$ and $\mathrm{Al}_{\mathrm{o}} / \mathrm{Al}_{\mathrm{d}}$ ratios) is evident in Table 1, both between horizons of a soil and within similar horizons (e.g., B horizons) among all four soils. B horizon carbon contents, $\mathrm{Fe}_{\mathrm{o}}$ / $\mathrm{Fe}_{\mathrm{d}}$ and $\mathrm{Al}_{\mathrm{o}} / \mathrm{Al}_{\mathrm{d}}$ ratios all follow the pattern red alder $>$ Douglas-fir > Tarklin > Fullerton; nearly the same pattern noted for sulfate and phosphate adsorption. Thus, we hypothesize that the blocking effects of organic matter on anion adsorption in this case are outweighed by the enhancing effects of maintaining noncrystalline $\mathrm{Fe}$ and $\mathrm{Al}$ hydrous oxides.

The results of both the laboratory column and field salt application studies corroborated the results of the adsorption isotherms. The red alder soil retained the

Table 2. Fluxes of anions in soil solution in control and salt-treated $\left[0.5\right.$ mol $(-) \mathrm{m}^{-2}$ each of $\mathrm{H}_{2} \mathrm{PO}_{4}^{-}, \mathrm{SO}_{4}^{2-}, \mathrm{NO}_{3}^{-}$, and $\mathrm{Cl}^{-}$as $\mathrm{Na}^{+}$salts] plots over a 2-yr period.

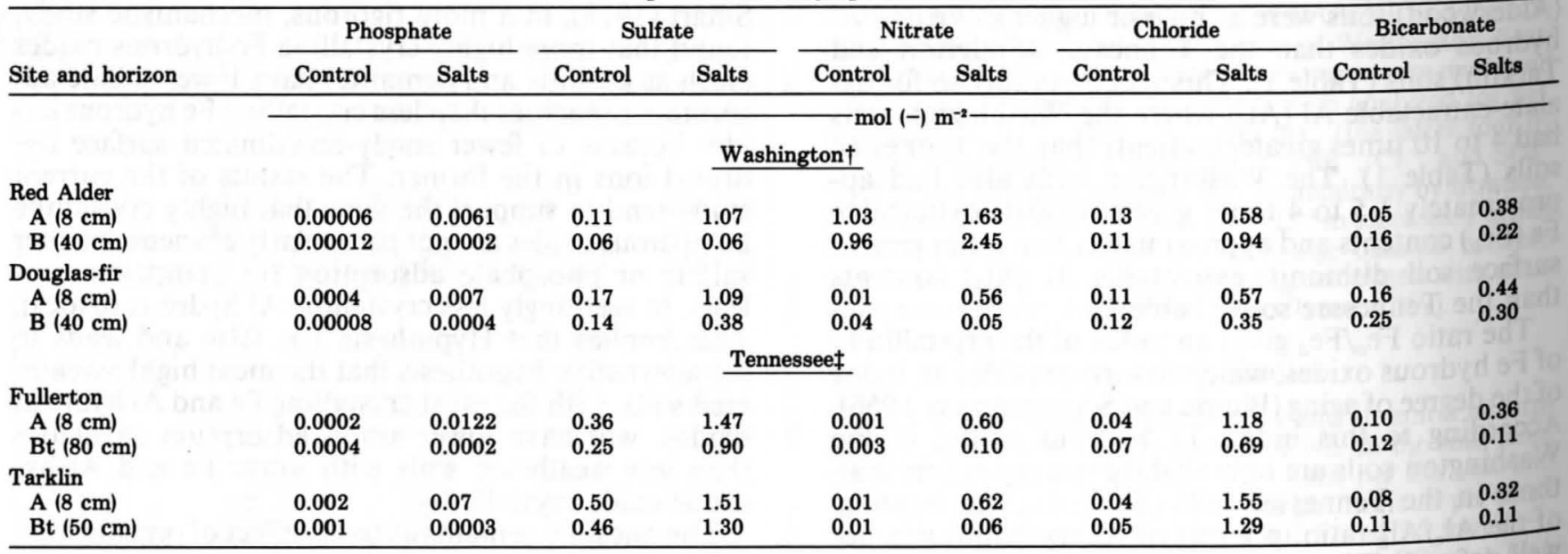


most phosphate, followed by the Douglas-fir, Fullerton, and Tarklin soils, respectively (Fig. 2 and Table 2). Phosphate adsorption apparently caused net desorption of native soil sulfate from A horizons of salttreated soils, both in laboratory column and field studies (Fig. 2 and Table 2). There also was a net sulfate release from all but the red alder B horizon in the column studies, apparently a result of phosphate inputs from A horizon leachates (Fig. 2). In the red alder soil, B horizon columns showed a net retention of sulfate, presumably due to the lower phosphate inputs from A horizon leachates and the greater sulfate adsorption capacity of this soil.

Both of the Washington Inceptisols retained applied sulfate in field studies, whereas neither of the Tennessee Ultisols did (Fig. 3). After 2 yr (and approximately $280 \mathrm{~cm}$ of leaching), the red alder soil showed no net sulfate export (in excess of control plots) and the Douglas-fir soil showed a net export (in excess of control) of only $0.24 \mathrm{~mol}(-) \mathrm{m}^{-2}$, or roughly $50 \%$ of applied sulfate (Table 2). On the other hand, the Fullerton and Tarklin soils showed net exports (in excess of control) of 0.65 and $0.84 \mathrm{~mol}(-) \mathrm{m}^{-2}$ (130 and $168 \%$ of applied sulfate) after only $130 \mathrm{~cm}$ of leaching (Table 2). (Annual leaching rates were lower in the Tennessee soils due primarily to higher evapotranspiration.)

Flux calculations in field lysimeter plots are subject to many uncertainties (one of which is the appropriate water flux to apply), and thus the apparent release of native soil sulfate from the Tennessee soils may have been an artifact. This was not the case in the laboratory column studies, however, where fluxes were accurately measured and clearly showed net sulfate release due to phosphate adsorption. In any case, the patterns of sulfate retention in B horizons in the field studies followed those of the adsorption isotherms, namely red alder $>$ Douglas-fir $>$ Fullerton $>$ Tarklin.

Hypothesis II was supported by the results of the laboratory and field salt application studies. No net $\mathrm{NO}_{3}^{-}$retention was observed in any of the soils in the column studies (Fig. 2). The $\mathrm{N}$-rich red alder soil showed a net release of $\mathrm{NO}_{3}^{-}$in both the laboratory column and field salt application studies (Fig. 2 and Table 2). This was likely due to release of native soil $\mathrm{NO}_{3}^{-}$in the column studies (Fig. 2) and nitrification in excess of $\mathrm{NO}_{3}^{-}$uptake in field studies (Van Miegroet and Cole, 1984). In contrast, the $\mathrm{NO}_{3}^{-}$applied to the N-limited Douglas-fir, Fullerton, and Tarklin plots in the field studies was almost completely retained in B horizons (Table 2). The differences in $\mathrm{NO}_{3}^{-}$mobility in laboratory vs. field studies in the latter soils appear to be due primarily to tree uptake because there was little net $\mathrm{NO}_{3}^{-}$retention in the organic matter-rich surface horizons in the field studies (Table 2). The possibility of microbial uptake in B horizons cannot be excluded, however.

Chloride was mobile in all soils in both laboratory and field salt studies (Fig. 2 and Table 3), confirming its chemical and biological inertness. The $\mathrm{Na}^{+}$-salt application studies do not provide adequate tests of $\mathrm{Hy}-$ pothesis III, however, because of the confounding effects of phosphate and sulfate adsorption on soil

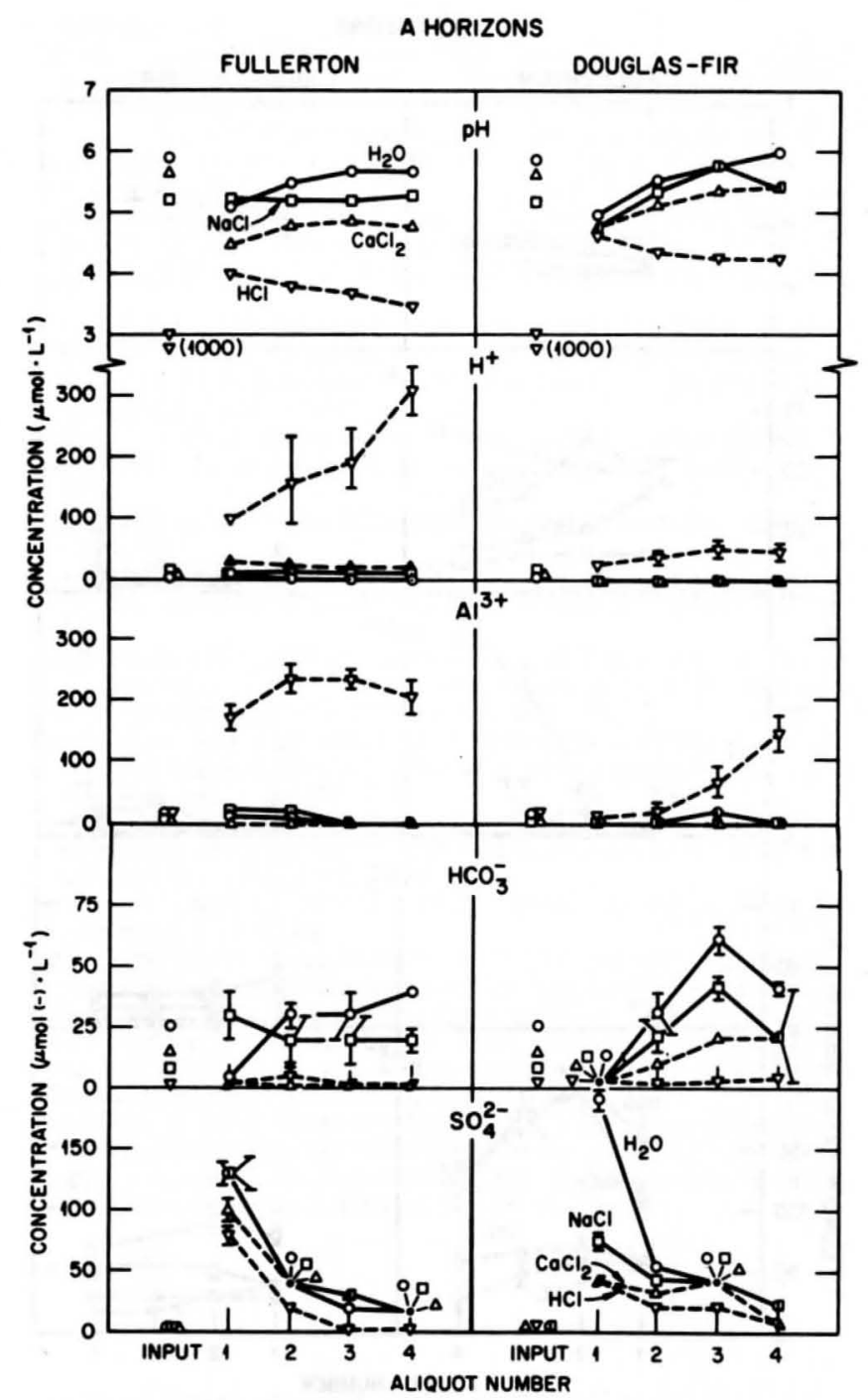

Fig. 3. $\mathrm{pH}, \mathrm{H}^{+}, \mathrm{Al}^{3+}, \mathrm{HCO}_{3}^{-}$, and $\mathrm{SO}_{4}^{2-}$ concentrations in leachates from $\mathrm{A}$ horizon soil columns treated with $\mathrm{H}_{2} \mathrm{O}, \mathrm{NaCl}, \mathrm{CaCl}_{2}$, and $\mathrm{HCl}$ at $1.0 \mathrm{mmol}(-) \mathrm{L}^{-1}$. (Standard deviations are given.)

solution $\mathrm{pH}$. Thus, Hypothesis III was tested in a series of column studies on the Douglas-fir and Fullerton soils involving chloride applications as $\mathrm{NaCl}$, $\mathrm{CaCl}_{2}$, and $\mathrm{HCl}$.

Table 3. Net export of $\mathrm{HCO}_{3}^{-}$and $\mathrm{SO}_{4}^{2-}$ with $\mathrm{H}_{2} \mathrm{O}, \mathrm{NaCl}, \mathrm{CaCl}_{2}$, and $\mathrm{HCl}$ treatments $\left[1 \mathrm{mmol}(-) \mathrm{L}^{-1}\right]$ to soil columns. $\dagger$

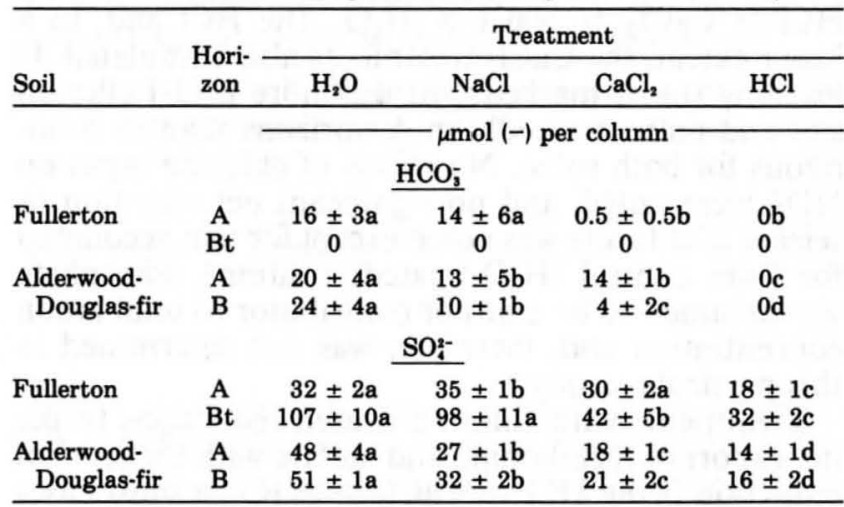

$\dagger$ Numbers not sharing the same letters are statistically different from one another, Duncan's Multiple Range Test, 95\% level. 


\section{B HORIZONS}

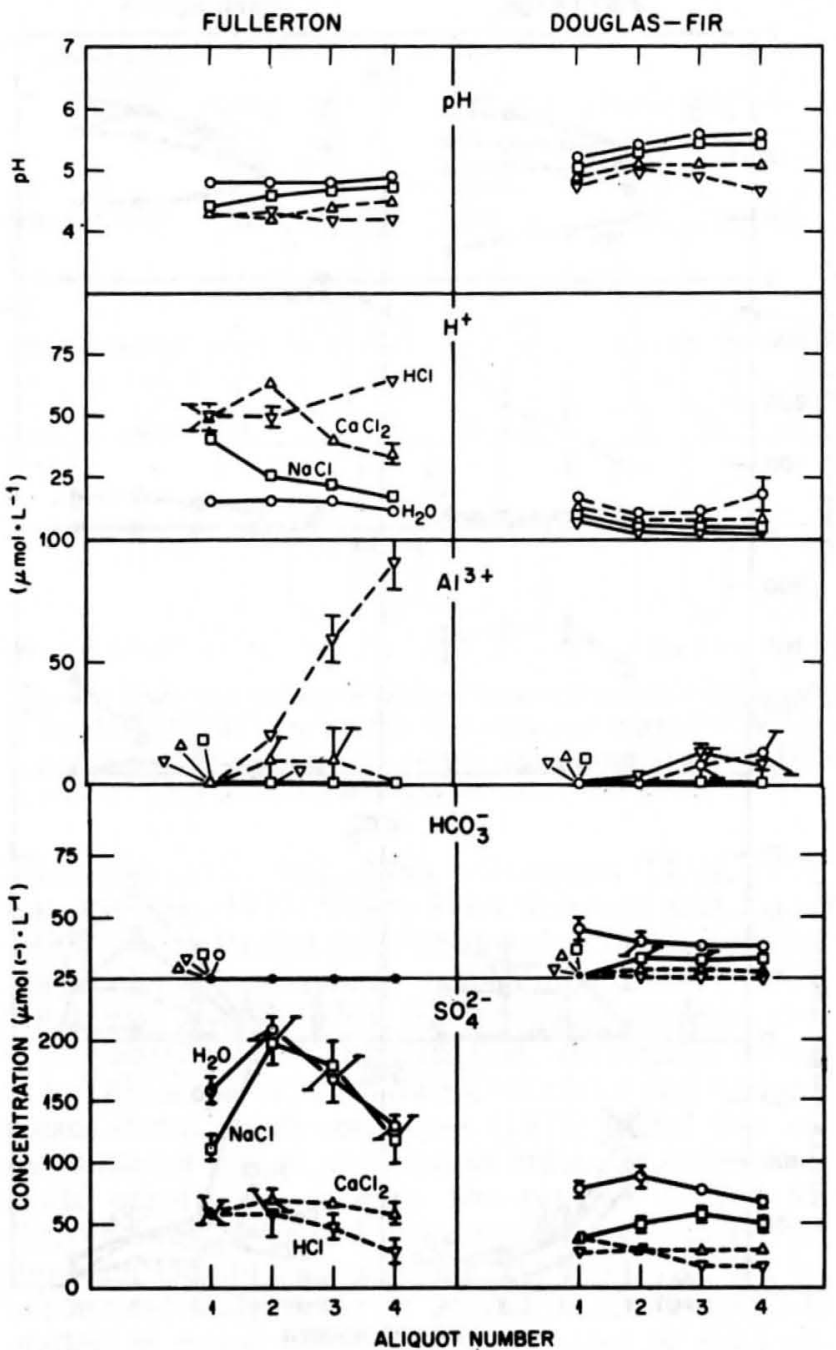

Fig. 4. pH, $\mathrm{H}^{+}, \mathrm{Al}^{3+}, \mathrm{HCO}_{3}^{-}$, and $\mathrm{SO}_{4}^{2-}$ concentrations in leachates from $\mathrm{B}$ horizon soil columns treated with $\mathrm{H}_{2} \mathrm{O}, \mathrm{NaCl}, \mathrm{CaCl}_{2}$, and $\mathrm{HCl}$ at $1.0 \mathrm{mmol}(-) \mathrm{L}^{-1}$. (Standard deviations are given.)

The chloride application studies supported Hypothesis III in that inputs of chloride, as salt or acid, caused lowered $\mathrm{pH}, \mathrm{HCO}_{3}^{-}$, and $\mathrm{SO}_{4}^{2-}$ concentrations in leachates as compared to water applications (Fig. 3 and 4). The effects depended on the cation associated with chloride input, with the degree of effect being $\mathrm{HCl}>\mathrm{CaCl}_{2}>\mathrm{NaCl}>\mathrm{H}_{2} \mathrm{O}$. The $\mathrm{HCl}$ and, to a lesser extent, the $\mathrm{CaCl}_{2}$ treatments also stimulated $\mathrm{Al}$ leaching (most markedly in the more acid Fullerton soil and more markedly in A horizons than in B horizons for both soils). No effects of chloride input on $\mathrm{NO}_{3}^{-}$were noted, and no significant net retention or release of chloride was noted except for that accounted for from control $\left(\mathrm{H}_{2} \mathrm{O}\right.$-treated) columns. Phosphate was assumed to be a minor contributor to total anion concentration and, therefore, was not determined in this particular study.

Treatments with chloride caused reductions in the net export of bicarbonate and sulfate with the level of reduction being $\mathrm{HCl}>\mathrm{CaCl}_{2}>\mathrm{NaCl}$ in most cases (Table 3). No net change in chloride export could be detected, due in part to the large background chloride (and background $\mathrm{Cl}^{-}$variability) in chloride-treated columns. Nitrate export was low ( $<1 \mathrm{mmol} /$ column) and not affected by treatment.

\section{SUMMARY AND CONCLUSIONS}

Laboratory and field studies tested hypotheses concerning anion movement and retention in forest soils. Two Ultisols (Fullerton and Tarklin series), both with deciduous forest cover in eastern Tennessee, and two Inceptisols (both Alderwood series), one with Douglas-fir and one with red alder forest cover in western Washington were studied. We hypothesized that sulfate and phosphate retention in the four forest soils would be related to $\mathrm{Fe}$ and $\mathrm{Al}$ oxide content, which in turn would be related to soil parent material and degree of weathering. This hypothesis was not supported by results of soil $\mathrm{Fe}$ and $\mathrm{Al}$ hydrous oxide analyses, adsorption isotherm determinations, or applications of sulfate and phosphate as $\mathrm{Na}^{+}$salts to laboratory columns and field plots. The Washington Inceptisols (especially the red alder site) adsorbed more sulfate and phosphate than the Tennessee Ultisols. Apparently, this was due to greater amorphous hydrous $\mathrm{Fe}$ and $\mathrm{Al}$ oxide contents in the former. $\mathrm{Hy}$ drous $\mathrm{Fe}$ and $\mathrm{Al}$ oxides in the Tennessee subsoils appeared to be more crystalline. Consequently, they were less able to adsorb sulfate and phosphate.

A second hypothesis that $\mathrm{NO}_{3}^{-}$retention was governed by biological processes was supported by laboratory and field results of $\mathrm{NaNO}_{3}$ application. No soil retained $\mathrm{NO}_{3}^{-}$in laboratory studies where forest floor and trees were excluded, but most of the applied $\mathrm{NO}_{3}^{-}$was retained in $\mathrm{B}$ horizons of all but the $\mathrm{N}$-rich red alder soil, suggesting tree uptake as a major cause of $\mathrm{NO}_{3}^{-}$immobilization in the ecosystem.

The third hypothesis stated that manipulations causing solution $\mathrm{pH}$ to rise would increase leaching of bicarbonate and adsorbed anions (and vice versa) and that inputs of mobile anions like chloride would lower solution $\mathrm{pH}$ and cause net anion retention. This hypothesis was supported by applications of $\mathrm{HCl}, \mathrm{NaCl}$, and $\mathrm{CaCl}_{2}$ (compared to $\mathrm{H}_{2} \mathrm{O}$ only) to soil columns. Chloride applications lowered solution $\mathrm{pH}$ and reduced the leaching bicarbonate and sulfate with the order of effectiveness being $\mathrm{HCl}>\mathrm{CaCl}_{2}>\mathrm{NaCl}$ for a given chloride concentration.

\section{REFERENCES}

Bertolacini, R.-J., and J.E. Barney. 1957. Colorimotric determination of sulfate with barium chloranilate. Anal. Chem. 29:281-283.

Blume, H.P., and U. Schwertmann. 1966. Genetic evaluation of profile distribution of aluminum, iron, and manganese oxides. Soil Sci. Soc. Am. Proc. 33:438-444.

Brackett, M.H. 1966. Alderwood soils series. M.S. thesis, Washington State Univ., Pullman.

Cole, D.W., and S.P. Gessel. 1965. Movement of elements through a forest soil as influenced by tree removal and fertilizer additions. p. 95-104. In C.T. Youngberg (ed.) Forest-soil relationships in North America. Proc. North Am. For. Soils Conf., 2nd, North Carolina State Univ., Raleigh. Oregon State University Press, Corvallis, OR.

Golterman, H.L., and R.S. Clymo (ed.). 1969. Methods for chemical analyses of fresh waters. IBP Handb. no. 8. International Biological Programme, London.

Grigal, D.F., and R.A. Goldstein. 1971. An integrated ordinationclassification analysis of an intensively sampled oak-hickory forest. J. Ecol. 59:481-492.

Guar, A.C. 1969. Studies on the availability of phosphate in soil as 
influenced by humic acid. Agrochimica 14:62-65.

Harter, R.D. 1969. Phosphorus adsorption sites in soils. Soil Sci. Soc. Am. Proc. 33:630-631.

Henderson, G.S., D.D. Huff, and T. Grizzard. 1977. Hydrologic characteristics of Walker Branch Watershed. p. 195-209. In D.L. Correll (ed.). Watershed research in North America. Smithsonian Institution, Edgewater, MD.

Hingston, F.J., R.J. Atkinson, A.M. Posner, and J.P. Quirk. 1967. Specific adsorption of anions. Nature 215:1459-1461

Johnson, D.W., and D.W. Cole. 1980. Anion mobility in soils: Relevance to nutrient transport from forest ecosystems. Environ. Int. 3:79-90.

Johnson, D.W., D.W. Cole, F.W. Horng, H. Van Miegroet, and D.E. Todd. 1981. Chemical characteristics of two forested Ultisols and two forested Inceptisols relevant to anion production and mobility. ORNL/TM-7646. Oak Ridge National Laboratory, Oak Ridge, TN

Johnson, D.W., and G.S. Henderson. 1979. Sulfate adsorption and sulfur fractions in a highly weathered soil under a mixed deciduous forest. Soil Sci. 128:34-40.

Johnson, D.W., and D.E. Todd. 1983. Some relationships among $\mathrm{Fe}, \mathrm{Al}, \mathrm{C}$, and $\mathrm{SO}_{4}^{2-}$ in a variety of forest soils. Soil Sci. Soc. Am. J. 47:792-800.

Knutsen, S.K. 1965. Hydrologic processes in thirty to thirty-fiveyear-old Douglas-fir and red alder in western Washington. M.S. thesis. Univ. of Washington, Seattle.

Kodama, H., and M. Schnitzer. 1977. Effect of fulvic acid on the crystallization of Fe (III) oxides. Geoderma 19:279-291.

Larsen, J.E., G.F. Warren, and R. Langston. 1959. Effect of iron, aluminum and humic acid on phosphorus fixation by organic soils. Soil Sci. Soc. Am. Proc. 23:438-440.

Lee, S.Y., D.C. Kopp, and D.A. Lietzke. 1984. Minerological characterization of west chestnut ridge soils. ORNL/TM-9361. Oak Ridge National Laboratory, Oak Ridge, TN.

Luxmoore, R.J. 1983. Water budget of an eastern deciduous forest stand. Soil Sci. Soc. Am. J. 47:785-791.

McColl, J.G., and D.W. Cole. 1968. A mechanism of cation transport in a forest soil. Northwest Sci. 42:134-140.

McKeague, J.A., and J.H. Day. 1966. Dithionite- and oxalate-extractable $\mathrm{Fe}$ and $\mathrm{Al}$ as aids in differentiating various classes of soils. Can. J. Soil Sci. 46:13-22.

Nye, P.H., and D.J. Greenland. 1960. The soil under shifting cultivation. Commonwealth Bureau of Soils Tech. Commun. no. 51. Commonwealth Agricultural Bureaux, Farnham Royal, Bucks,
England.

Olson, S.R. and L.E. Sommers. 1982. Phosphorus. In A.L. Page et al. (ed.). Methods of soil analysis, Part 2. 2nd ed. Agronomy 9:403430.

Parfitt, R.L., and R.S.C. Smart. 1978. The mechanism of sulfate adsorption on iron oxides. Soil Sci. Soc. Am. J. 42:48-50.

Peters, L.N., D.F. Grigal, J.W. Curlin, and W.J. Selvidge. 1970 Walker Branch Watershed Project: Chemical, physical, and morphological properties of the soils of Walker Branch Watershed. ORNL/TM-2968. Oak Ridge National Laboratory, Oak Ridge, TN.

Rajan, S.S.S. 1979. Adsorption and desorption of sulfate and charge relationships in allophanic clays. Soil Sci. Soc. Am. J. 43:65-69.

Reuss, J.O. 1978. Simulation of nutrient loss from soil due to rainfall acidity. Ecol. Model. 11:15-38.

Reuss, J.O. 1983. Implications of the $\mathrm{Ca}-\mathrm{Al}$ exchange system for the effect of acid precipitation on soils. J. Environ. Qual. 12:591595.

SAS Institute, Inc. 1982. SAS user's guide: Statistics. SAS Institute, Cary, NC.

Schwertmann, U. 1966. Inhibitory effect of soil organic matter on the crystallization of amorphous ferric hydroxide. Nature 212:645646.

Singh, B.R. 1984. Sulfate sorption by acid forest soils: 2 . Sulfate adsorption isotherms with and without organic matter and oxides of aluminum and iron. Soil Sci. 138:294-297.

Singh, B.B., and J.D. Jones. 1976. Phosphorus sorption and desorption characteristics of soil as affected by organic residues. Soil Sci. Soc. Am. J. 40:389-394.

Struth, P.H., and D.H. Sieling. 1950. Effect of organic anions on phosphate precipitation by iron and aluminum as influenced by pH. Soil Sci. 169:205-213.

Stumm, W., and J.J. Morgan. 1970. Aquatic chemistry. Wiley-Interscience, New York.

U.S. Department of Agriculture. 1972. Soil survey methods and procedures for collecting soil samples. Soil Survey Investigation Rep. no. 1. U.S. Government Printing Office, Washington, DC.

Van Miegroet, H., and D.W. Cole. 1984. The impact of nitrification on soil acidification and cation leaching in a red alder (Alnus rubra) ecosystem. J. Environ. Qual. 13:586-590.

Wesseling, J. 1962. Some solutions of the steady-state diffusion of carbon dioxide through soils. Neth. J. Agric. Sci. 10:109-117.

Yopps, J.A., and D.W. Fuerstenau. 1964. The zero point of charge of alpha-aluminum. J. Colloid Sci. 19:61-71.

\title{
Physical and Chemical Soil Properties of Three Big Sagebrush Subspecies ${ }^{1}$
}

\author{
Sherman R. Swanson, Gerald H. Simonson, and John C. Buckhouse ${ }^{2}$
}

\section{ABSTRACT}

The three subspecies of Artemisia tridentata Nutt. typically occupy qualitatively different sites. Wyoming big sagebrush, $A$. $t$. ssp. wyomingensis, commonly grows in Aridisols; mountain big sagebrush, $A$. $t$. ssp. vaseyana, commonly lives in Mollisols at a higher average elevation; and basin big sagebrush, $A$. $t$. ssp. tridentata, occurs in deep soils of either order. This study evaluated some physical and chemical characteristics of surface and subsurface soil horizons of soils occupied by each subspecies in four widely spaced Oregon locations. Most soil chemical characteristics showed no significant differences between subspecies. Interaction between location and subspecies often indicated that analysis should proceed at each individual location. The Frenchglen location had the greatest elevational differences between sites and also had most statistically significant soil differences between subspecies. Many of the measured characteristics are interrelated and differences in them prob-

\footnotetext{
Research was supported through funding provided by USDAARS and the Eastern Oregon Agricultural Research Center. Technical Paper no. 6920. Oregon Agricultural Experiment Station, Corvallis. Received 31 De. 1984.

${ }^{2}$ Range Extension Specialist, Univ. of Nevada-Reno, Reno NV 89512; Professor, Soil Science; and Associate Professor, Range Resources, Oregon State Univ. Corvallis, OR 97331.
}

ably are influenced by elevation-related variation in climate. Surface horizons of Frenchglen, $\boldsymbol{A}$. $\boldsymbol{t}$. ssp. vaseyana sites had lower $\mathrm{pH}$, base saturation, and exchangeable $\mathrm{Na}^{+}$and higher organic matter, cation exchange capacity, and water retention at $-1.50 \mathrm{MPa}$ than surface horizons of $A$. $t$. ssp. wyomingensis sites. Fewer surface soil characteristics of $\boldsymbol{A}$. $\boldsymbol{t}$. ssp. tridentata sites were significantly different. In deeper soil horizons at Frenchglen, $A . t$. ssp. vaseyana sites had lower $\mathrm{pH}$ and base saturation than $A$. $t$. ssp. tridentata sites.

Additional Index Words: Artemisia tridentata, organic matter, cation exchange capacity, base saturation, soil depth, soil texture, soil-water retention.

Swanson, S.R., G.H. Simonson, and J.C. Buckhouse. 1986. Physical and chemical soil properties of three big sagebrush subspecies. Soil Sci. Soc. Am. J. 50:783-787.

$\mathrm{V}$ EGETATION AND SOIL CHARACTERISTICS are interdependent integrators of environmental factors. Understanding the indicator value of vegetation can be useful to land managers, especially where soil and vegetation are correlated over broad areas of the 